\title{
EFFECTS OF AFLATOXIN ON SOYBEAN
}

\author{
Gloria Chinasa NNAMANI $^{1}$, Andrew Shema GANA $^{2}$, Aondover SHAAHU $^{1 *}$, \\ Titus Saanmoiyol MSAAKPA ${ }^{5}$, Prince Chisom LEMIBE ${ }^{1}$, Maxwell Arinze NNAMANI ${ }^{3}$, \\ Emmanuel Obinna NWANYANWU ${ }^{4}$ \\ ${ }^{1}$ Soybean Research Programme, National Cereals Research Institute, P. M. B 8, Badeggi, \\ Niger State - Nigeria. \\ ${ }^{2}$ Plant Breeding and Seed Science, Federal University of Technology, Minna, Niger State - Nigeria. \\ ${ }^{3}$ Federal Polytechnic, Bida, Niger State - Nigeria. \\ ${ }^{4}$ Teesside University, Middlesbrough - United Kingdom. \\ ${ }^{5}$ Plant Breeding and Seed Science, Federal University of Agriculture, Makurdi, Benue State - Nigeria. \\ ${ }^{*}$ Corresponding author. E-mail: iorpen001@gmail.com
}

\begin{abstract}
Aflatoxin is widely known as human and animal carcinogen that can contaminate food and feed stuffs. It is also known as a major food quality problems all over the world. Aflatoxins are group of naturally occurring mycotoxins that are mainly produced by fungus Aspergillus flavus and Aspergillus parasiticus. There are seven (7) major groups of mycotoxins reported, which produced by different species of toxigenic fungal genus. The production of mycotoxins from these toxigenic fungi based on the surrounding intrinsic and extrinsic environments. These groups of mycotoxins that contaminates grains, foods and animal feeds are known as Aflatoxin, Trichothecene, Ochratoxins, Ergot alkaloid (Ergolin), Zearalenone, Patulin and Fumonisins. These mycotoxins could cause health hazards and death for human and animals by affecting the mammalian cells, causing some problems in normal cell function and a wide variety of clinical symptoms of diseases. These seven groups of mycotoxin are varied in their toxicity depending on the infection host i.e. human or animal, and also the immunity of human and animals. Soybean is an important food and nutritional security crop world widely. It is also promoted due to its potentiality in proteins for both adults as an infant weaning food.
\end{abstract}

Keywords: Aflatoxin, human, livestock, soybean, substrate.

\section{Introduction}

Aflatoxins $\left(\mathrm{AF}_{3}\right)$ are widely known as a group of highly toxic secondary metabolites produced mainly by the filamentous fungi known as Aspergillus flavus and Aspergillus parasiticus. Aflatoxins are also the most studied and widely known mycotoxins [WILLIAMS $\&$ al. 2004]. And it was first discovered in the early 1960's in United Kingdom to describe the toxins associated with contaminated animal feed called peanut and the loss turkey in England. Aflatoxins probably grow on agricultural crops like cereals, grains, nuts and dried fruits. Human foods and animal feeds produced from fungi contaminated agricultural crops are highly hazardous to health for both human and animals. These kind of toxigenic fungi could grow under optimum conditions of temperature and humidity either during plant, or after crop harvesting, at crop storage time and during the processed food or feed products. [RICHARD, 2007]. The functions of mycotoxins are yet to be understood; perhaps they could function as an insecticide, and might play a role in fighting against the plant defence to the fungus in some means to complete their ecological role in nature. Mycotoxins are not 
detectable by the immune systems of human and animals and also they are non-pretentious in nature.

However, aflatoxin could accumulate through the food chain therefore causing a very serious health concern to both human and animals. Aflatoxins are highly mutagenic and carcinogenic in nature and as well it has been associated with various diseases, like aflatoxicosis. The contamination of aflatoxins is influenced by environmental factors like agronomic practices and geography. Aflatoxin B1 have been reported as the most common in food and also amongst the most potent genotoxic and carcinogenic aflatoxin, and it presence in food such as corn, milk and peanuts might enhance a person's risk of cancer of the liver. Contamination of aflatoxins is most acute and widespread in warm, humid climates of the tropical and subtropical regions of the world due to the fact that production of aflatoxins is optimal at relatively high temperatures [HUDLER, 1998].

Aflatoxin B1 is produced both by Aspergillus flavus and Aspergillus parasiticus. Aflatoxin M1 is the main metabolite of aflatoxin B1 in both human and animals which might be present in milk from animals been fed with animal's feed that are contaminated aflatoxin B1. Moreover, a report in LOPEZ-GARCIA \& al. (1999) described that food and feeds contaminated with mycotoxins are unpredictable and unavoidable, which makes it a unique challenge for food and feeds safety. Food safety refers to minimizing the presence of those hazards, whether acute or chronic, that could make food dangerous to the health of those consuming it. The presence of mycotoxins in food totally makes the food products hazardous for human consumption, which eventually leads to the post-harvest loss and also becomes a problem to food security. The proliferation of different kinds of fungi in agricultural products causes low yield and consequential economic losses [ADEYEYE, 2016]. The different kind of fungi, their substrates and mycotoxins are shown in Table 1.

Table 1. Different kinds of fungi, their substrate and mycotoxins

\begin{tabular}{|c|c|c|}
\hline Fungi & Substrate & Mycotoxins \\
\hline Aspergillus flavus & Maize, groundnut, oilseed, cottonseed & \multirow{3}{*}{$\begin{array}{l}\text { Aflatoxin (carcinogenic to } \\
\text { human) }\end{array}$} \\
\hline Aspergillus parasiticus & Maize, groundnut, oilseed, cottonseed & \\
\hline Aspergillus nomius & Maize, groundnut, oilseed, cottonseed & \\
\hline Aspergillus ochraceus & Bakery Wheat & \multirow{2}{*}{$\begin{array}{l}\text { Ochratoxin (Potentially } \\
\text { carcinogenic) }\end{array}$} \\
\hline Aspergillus carbonarius & Grapes, Wine, Coffee & \\
\hline Fusarium oxysporum & Wheat, Barley, Maize & $\begin{array}{l}\text { Fumonisins (Hepatotoxic } \\
\text { and Nephrotoxic) }\end{array}$ \\
\hline Fusarium sp. & Wheat, Barley, Maize & T-2 Toxin \\
\hline Penicillium verrucosum & Wheat, Barley, Maize & $\begin{array}{l}\text { Ochratoxin (Potentially } \\
\text { carcinogenic) }\end{array}$ \\
\hline Claviceps purpurea & Rye & Ergot Alkaloid \\
\hline Stachybotrys sp. & Hay & Satratoxin \\
\hline
\end{tabular}

Source: BENNETT \& KLICH, 2003.

\section{Health hazard effects of mycotoxin for human and animals}

In JUAN-GARCIA \& al. (2013), the general symptoms that surfaces after the intake of foods contaminated with mycotoxins or indirectly from consumption of meats or drinking milk from animals that have been fed feeds contaminated with mycotoxins are diarrhea, weakness, headache, fatigue, difficult concentration, light sensitivity, short memory, increase thirst, unusual skin sensations, morning stiffness, chronic cough, joint pain, shortness of 
Gloria Chinasa NNAMANI \& al.

breath, increase urinary frequency, abdominal pain, bloating, blurred vision, sinus congestion, mood swings, sweats red eyes. These symptoms could as well leads to a serious health issue like cancer, acute pulmonary haemorrhage, kidney toxicity, immune suppression, depression, autism, chronic fatigue syndrome, neurotoxicity, birth defects and aplastic anaemia. These symptoms depends on the infected host i.e. human and animal and also the immune system of the host [SMITH \& al. 1995].

Furthermore, aflatoxins are very poisonous and its grows in soil, decomposing vegetation, grains and hay of major found in hot, humid climates, colonizing mainly on the aerial parts of the plants [MARIN \& al. 2013]. Mostly aflatoxins have similar structures and it have earned a significant attention due to their dangerous effects on human and animals likewise the international trade of foodstuffs. There are about 20 recognised kinds of aflatoxins are which are basically classified into aflatoxin B1 (AFB1), B2, G1, G2, M1 and M2 depending on thy structure, fluorescent characteristics and chromatography [EPHREM, 2015]. Below is Figure 1 showing the chemical structure of aflatoxin, B1, B2, G1, G2, M1 and $\mathrm{M} 2$.

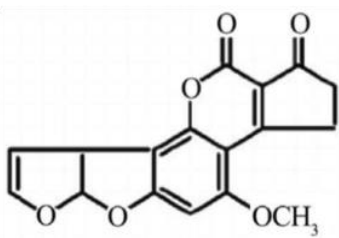

Aflatoxin B1

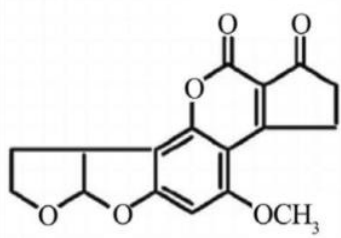

Aflatoxin B2

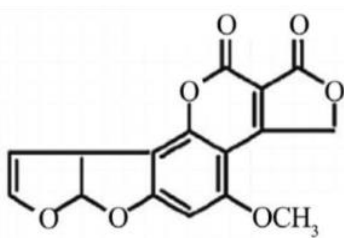

Aflatoxin G1

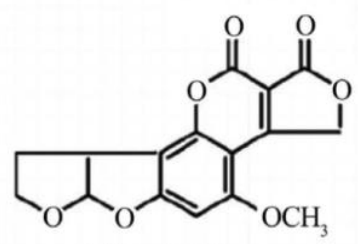

Aflatoxin G2

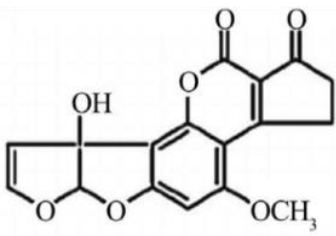

Aflatoxin M1

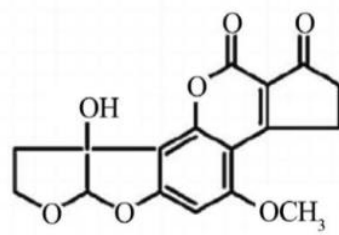

Aflatoxin M2

Figure 1. The chemical structure of aflatoxin, B1, B2, G1, G2, M1 and M2.

Source: MARIN \& al. (2013)

Aflatoxin B1 is very high in toxicity and mainly metabolized by liver into AFB1-8, 9-exo-epoxide and 8, 9-endo-epoxide which normally binds to DNA to form 8,9-dihydro-8(N7-guanyl)-9-hydroxy-(AFB1-N7-Gua) and AFB1-N7-Gua can be converted to two secondary lesion which is an apurinic site in which more stable ring is opened. This shows that aflatoxins have an effect on amino acid metabolism. The main human cytochrome P450 (CYP) enzymes involved in aflatoxin metabolism are known as CYP3A4, 3A5, 3A7 and 1A2 respectively [MARIN \& al. 2013].

As it was reported in JEF \& al. (2015), drought and stress enhances the spread of aflatoxin in the field and also could be produced due to inadequate drying of crops that have been contaminated with aflatoxins before storage or crops been stored under humid environment. Due to aflatoxin firmness to severe processes of baking, roasting, cooking and extrusion, it's induces a tremendous problem in processed foods, for example bakery and 
roasted nuts products and it could be found at the same time or alone, as well as co-occurring with other mycotoxins such as Ochratoxin A (OTA).

\section{Ways of controlling mycotoxins}

However, there four (4) ways in which the harmful effects of mycotoxin contamination food could be minimized:

1. By preventing contamination in the field through proper handling of crops;

2. Separation of contaminated materials from the healthy food commodity;

3. Reducing mycotoxin content in food and feed;

4. Proper treatment of exposed individuals.

A proper agronomic practices such as growing resistant crop varieties, soil tillage, crop rotation, insect control, chemical and biological control of plant diseases are major means in which mycotoxin contamination crops could be reduced in the field [EDWARDS, 2004]. In addition, a proper harvest and a good storage environment are very important in other to prevent fungal proliferation and accumulation of mycotoxin in harvest crops [JACOBSEN, 2014]. Food processing could initiate mycotoxins in food and feed raw material by physical removal, chemical transformation which could result in metabolites of lower or higher toxicity, release from masked or entrapped forms which might enhance bioavailability, enzymatic detoxification, and adsorption to solid surfaces.

\section{Soybean as an important commodity for both human and livestocks}

Soybean (Glycine $\max$ (L.) Merr.) are widely known as a leguminous crop, originated from Asia and was later introduced the USA in the year 1765 by Samuel Bowen [BRACHFELD \& CHOATE, 2007]. Carl Linnaeus first introduced the genus name Glycine during his first edition of General Plantarum. The word glycine was derived from Greek work "glykys", which means sweet, and it refers to the sweetness of the pear-shaped edible tubers which was produced by Native American legume. In 1917, Merrill proposed the scientific name, G. $\max ($ L.) Merrill., which has known become the official name of this useful and live saving plant.

Soybean has been reported severally as a very good source of protein and dietary fiber and also the only vegetable with complete protein due to the fact that it has the capability to lower the bad cholesterol levels (LDI) in the body [HOFFMAN \& FALVO, 2004]. The plantation of soybean in Nigeria commenced in the northern part of the country in year 1900s, and it has been fasten spread in almost the countries of the nation [SHURTLEFF \& AOYAGI, 2007]. In DUGJE \& al. (2009), the cultivation of soybean is usually in $6^{\text {th }}$ and $7^{\text {th }}$ month of the year (June/July), at the peak of the rainy seasons and harvested in $10^{\text {th }}$ and $11^{\text {th }}$ month of same year (October/November).

However, soybean was considered as an important crop in the year 1910s due to its use in crop rotation as a method of nitrogen fixation. The useful crop has played an important role in USA after the World War 1. The drought regions of the USA were able to regenerate their soil fertility and therefore enhanced their productivity that met with Government demands, due to the nitrogen fixation in soybean.

Soybean contain a high nutritional value of $40 \%$ protein and has best oil quality content of about $20 \%$ among other oilseed crops, depending on the genes and environmental factors. Soybean oil is unsaturated fatty acids, which is cholesterol free due to its high content of polyunsaturated fatty acid, and it is also digestible [HOFFMAN \& FALVO, 2004]. It has been globally known as one of the most prominent crop. Soybean enhances soil fertility by 
Gloria Chinasa NNAMANI \& al.

fixing the nitrogen in the soil which results in improving the crop yield for a better incomes. It is called the "miracle seed" because of its potentiality in supplying edible protein vegetable oil for human and animal consumption. Soybeans are recently the number one widely grown oilseed in the world. Soybean plant is known as an oilseed rather than pulse crop. About $85 \%$ of the global soybean crop is been proceed into soybean meal and vegetable oil. The demand for soybean is increasing tremendously to mirror the growth of global population for quality oil and protein content [OSHO, 2003]. The nutritional value of soybean (per $100 \mathrm{~g}$ ) is shown in Table 2.

Table 2. Illustrating the nutritional value of soybean (per $100 \mathrm{~g}$ )

\begin{tabular}{clcccc}
\hline S/N & SOYBEAN NUTRITIONS & VALUE & S/N & SOYBEAN NUTRITIONS & VALUE \\
\hline 1 & Energy & $466 \mathrm{kcal}$ & 22 & Fat & $19.94 \mathrm{~g}$ \\
\hline 2 & Carbohydrates & $30.2 \mathrm{~g}$ & 23 & Saturated & $2.89 \mathrm{~g}$ \\
\hline 3 & Sugars & $7.3 \mathrm{~g}$ & 24 & Monounsaturated & $4.4 \mathrm{~g}$ \\
\hline 4 & Protein & $36.49 \mathrm{~g}$ & 25 & Polyunsaturated & $11.26 \mathrm{~g}$ \\
\hline 5 & Tryptophan & $0.59 \mathrm{~g}$ & 26 & Water & $8.54 \mathrm{~g}$ \\
\hline 6 & Threonine & $1.77 \mathrm{~g}$ & 27 & Vitamin A & $1 \mathrm{mg}$ \\
\hline 7 & Isoleucine & $1.97 \mathrm{~g}$ & 28 & Vitamin B6 & $0.4 \mathrm{mg}$ \\
\hline 8 & Leucine & $3.31 \mathrm{~g}$ & 29 & Vitamin C & $6.0 \mathrm{mg}$ \\
\hline 9 & Lysine & $2.71 \mathrm{~g}$ & 30 & Vitamin K & $47 \mathrm{mg}$ \\
\hline 10 & Methionine & $0.55 \mathrm{~g}$ & 31 & Calcium & $277 \mathrm{mg}$ \\
\hline 11 & Phenylalanine & $2.12 \mathrm{~g}$ & 32 & Iron & $15.7 \mathrm{mg}$ \\
\hline 12 & Tyrosine & $1.54 \mathrm{~g}$ & 33 & Magnesium & $280 \mathrm{mg}$ \\
\hline 13 & Valine & $2.03 \mathrm{~g}$ & 34 & Phosphorus & $704 \mathrm{mg}$ \\
\hline 14 & Arginine & $3.15 \mathrm{~g}$ & 35 & Potassium & $1797 \mathrm{mg}$ \\
\hline 15 & Histidine & $1.1 \mathrm{~g}$ & 36 & Sodium & $2 \mathrm{mg}$ \\
\hline 16 & Alanine & $1.92 \mathrm{~g}$ & 37 & Zinc & $4.9 \mathrm{mg}$ \\
\hline 17 & Aspartic acid & $5.12 \mathrm{~g}$ & 38 & Phosphorus & $704 \mathrm{mg}$ \\
\hline 18 & Glutamic acid & $7.87 \mathrm{~g}$ & 39 & Potassium & $1797 \mathrm{mg}$ \\
\hline 19 & Glycine & $1.88 \mathrm{~g}$ & 40 & Sodium & $2 \mathrm{mg}$ \\
\hline 20 & Proline & $2.38 \mathrm{~g}$ & 41 & Zinc & $4.9 \mathrm{mg}$ \\
\hline 21 & Serine & $2.36 \mathrm{~g}$ & & &
\end{tabular}

Furthermore, soybean is complete protein because it contains all nine (9) essential amino acids. The high content of sulphur containing amino acids servers as storage protein in soybean varieties, but their significant reduces ones their the crops encounter challenges in germination. It is a significant source of protein for some people, especially vegetarian, as it serves as meat to the vegetarians [RIZZO \& BARONI, 2018]. Soybeans contain vitamins, A, B6, B12, C, and K. These chemical compounds cannot be synthesized in sufficient quantities by an organism and must be obtained from the diet.

However, aflatoxin disease is a not really a problem to soybean because of the little amount of zinc oxide of about $0.01 \mathrm{Mg} / \mathrm{g}$, which is bound to phytic acid [IRVING, 1971]. A report in HOWELL (1968) shows that Aflatoxin producing strains of Aspergillus flavus can be grown on soybean seed in the laboratory, that the quantity of aflatoxins produced is much lower compared with other commodities. The occurrence of both Aspergillus flavus and aflatoxins in soybean is basically very low. The report also indicates that in the 1965 and 1966, Aspergillus flavus could not been isolated from more than three thousand and one hundred $(3,100)$ samples of soybean seed examined. Another report in SHOTWELL \& al. (1969), demonstrated that only 2 of 866 soybean samples contained aflatoxins. So many reasons have been proposed for the resistance of soybean to Aspergillus flavus such as 
unfriendly moisture conditions for the fungus during the time of maturity of soybean, development of seeds in a closed pod, or it might be possible that the soybean seed comprised an inhibitor which could prevent fungus growth in soybean [HOWELL, 1968]. Soybean contains anti nutritional factors such as trypsin-chymotrypsin inhibitors. Although partially cooking of soybean reduces the proteinase inhibitor in soybean thereby producing a quality food [LIENER \& TOMLINSON, 1981]. HENSARLING \& al. (1983), recorded that the increased growth of Aspergillus flavus and Aspergillus parasiticus enhance toxin production, after the cooking of soybeans, soybean flour, or soybean-based medium, might indicate that heat-labile seed constituents such as proteinase inhibitors have an antifungal effect. However, this increase has rather been attributed to the availability of zinc, an essential trace element for aflatoxin synthesis and to the presence of phytate [MARSH \& al. 1975]. Total aflatoxin production with non-autoclaved soybeans was only $0.34 \mathrm{mg}$ per $100 \mathrm{~g}$ as compared to 6.85 mg per $100 \mathrm{~g}$ for autoclaved soybeans. A report in GUPTA \& VENKITASUBRAMANIAN (1975), indicates that the total number of aflatoxin production with nonautoclaved soybeans was only $0.34 \mathrm{mg}$ per $100 \mathrm{~g}$ as compared to $6.85 \mathrm{mg}$ per $100 \mathrm{~g}$ for autoclaved soybeans.

\section{Conclusion}

Aspergillus flavus is among the dominating species colonizing the soybean seed surface. Exposition of soybeans to high temperature even for a short period promotes high production of aflatoxin diseases. Mycotoxins do not only pose health risk to human and livestock, but also impact global economy, and food safety. Since mycotoxins are ubiquitous and they can appear everywhere in every commodity thereby causing health and economic challenges, appropriate and environmentally friendly prevention and control strategies shall be given priority. Moreover the government shall consider the use of (biotechnological) molecular approaches to control mycotoxins [GIZACHEW \& al. 2016]. Soybean varieties had acceptably low mycotoxin levels. Soybean has proven itself as an excellent nutrient source of protein, oil, and other small molecules. The demand for soybean consumption increased as expected in the past decade.

However, it can be promoted as a safe and nutritious food including for weaning, with good agricultural practices helping to ensure that contamination remains low. Given its importance as a major protein source in the human and livestock diet, there is a need to increase the cultivation and consumption of soybean in Nigeria. However, there is need for educating farmers on mycotoxin contamination in food and feeds to ensure better standards to safeguard the health of the consumers regarding these fungal metabolites. A larger surveillance on these toxins should be done world widely for a range of susceptible crops, as some weather is more conducive for mycotoxin production.

\section{Notes on contributors}

Gloria Chinasa NNAMANI is biotechnologist/Researcher, currently working on evaluation of soybean advanced lines.

Andrew Shema GANA is a professor of plant bleeding in the University of Technology, Minna.

Aondover SHAAHU is a PhD student/Researcher, currently working on soybean breeding and evaluation of advanced lines.

Titus Saanmoiyol MSAAKPA is an associate professor at Federal University of Agriculture, Makurdi, Benue State. His work focused on seed physiology. 

evaluation.

Prince Chisom LEMIBE is an agronomist/Researcher, his work is focused on weeds Maxwell Arinze NNAMANI is a Computer Scientist and currently working on Microsoft
designs.

Emmanuel Obinna NWANYANWU is a computer Engineer. His work is focused on hardware designs.

\section{References}

ADEYEYE S. A. O. 2016. Fungal mycotoxins in foods: A review. Cogent Food \& Agriculture. 2(1). https://doi.org/ 10.1080/23311932.2016.1213127

BENNETT J. W. \& KLICH M. 2003. Mycotoxins. Clinical Microbiology Reviews. 16(3): 497-516. https://doi.org/10.1128/cmr.16.3.497-516.2003

BRACHFELD A. \& CHOATE M. 2007. Eat your food! Gastronomical glory from garden to gut: a Coastalfields cookbook, nutrition textbook, farming manual and sports manual. Coastalfields. Arvada, CO, U.S.A.: $275 \mathrm{pp}$.

DUGJE I. Y., OMOIGUI L. O., EKELEME F., BANDYOPADHYAY R., KUMAR L. P. \& KAMARA A. Y. 2009. Farmers' Guide to Soybean Production in Northern Nigeria. International Institute of Tropical Agriculture (IITA).

EDWARDS S. G. 2004. Influence of agricultural practices on Fusarium infection of cereals and subsequent contamination of grain by trichothecene mycotoxins. Toxicology Letters. 153: 29-36. https://doi.org/10.1016/j.toxlet.2004.04.022

EPHREM G. 2015. Aflatoxin Contamination in Groundnut (Arachis hypogaea L.) caused by Aspergillus species in Ethiopia. Journal of Applied \& Environmental Microbiology. 3(1): 11-19.

GIZACHEW D., SZONYI B., TEGEGNE A., HANSON J. \& GRACE D. 2016. Aflatoxin contamination of milk and dairy feeds in the Greater Addis Ababa milk shed, Ethiopia. Food Control. 59: 773-779.

GUPTA S. K. \& VENKITASUBRAMANIAN T. A. 1975. Effect of zinc Tricarboxylic Acid cycle Intermediates and Enzymes in Relation to Aflatoxin Biosynthesis. Department Biochemistry, Vallabhbhai Patel Chest Institute, University of Delhi, Delhi-7, India.

HENSARLING T. P., JACKS T. J., LEE L. S. \& CIEGLER A. 1983. Production of aflatoxins on soybean and cottonseed meals. Mycopathology. 83: 125-127.

HOFFMAN J. R. \& FALVO M. J. 2004. Protein - Which Is Best? Journal of Sports Science \& Medicine. 3: 118130.

HOWELL R. W. 1968. Mycotoxin research in oilseeds, p. 61-66. In: HERZBERG M. (Ed.). Toxic microorganisms, mycotoxins-botulism. U. S. Department of Interior, Washington D.C.

HUDLER GEORGE W. 1998. Magical Mushrooms, Mischievous Molds: The Remarkable Story of the Fungus Kingdom and Its Impact on Human Affairs. Princeton University Press.

IRVING G. W. 1971. Aflatoxin research, a review of agriculture research service studies. U.S. Department of Agriculture, ARS. 20-17: 11 pp.

JACOBSEN B. J. 2014. Good agricultural and harvest practices to reduce mycotoxin contamination in wheat in temperate countries: 209-219. In: LESLIE J. F. \& LOGRIECO A. F. (Eds.) Mycotoxin reduction in grain chains. New Delhi: Wiley Blackwell.

JEF L., JIA-SHENG W. \& KELLY J. 2015. Serum aflatoxin B1-lysine adduct level in adult women from Eastern Province in Kenya depends on household socio-economic status: A cross sectional study. Social Science and Medicine Journal. 146: 104-110.

JUAN-GARCÍA A., MANYES L., RUIZ M. J. \& FONT G. 2013. Applications of flow cytometry to toxicological mycotoxin effects in cultured mammalian cells: a review. Food and Chemical Toxicology. 56: 40-59. https://doi.org/10.1016/j.fct.2013.02.005

LIENER I. E. \& TOMLINSON S. 1981. Heat inactivation of protease inhibitors in a soybean line lacking the Kunitz trypsin inhibitor. Food Science. 46: 1354-1356.

LOPEZ-GARCIA R., PARK D. L. \& PHILLIPS T. D. 1999. Integrated mycotoxin management systems. Food, Nutrition and Agriculture, FAO, http://www.fao.org/docrep/X2100T/x2100t07.htm

MARIN S., RAMOS A. J., CANO-SANCHO G. \& SANCHIS V. 2013. Mycotoxins; Occurrence, toxicology, and exposure assessment. Food and Chemical Toxicology. 60: 218-37.

MARSH P. B., SIMPSON M. E. \& TRUCKSESS M. W. 1975. Effects of trace metals on the production of aflatoxins by Aspergillus parasiticus in the low Applied Microbiology. 30: 52-57. 


\section{EFFECTS OF AFLATOXIN ON SOYBEAN}

OSHO S. M. 2003. The processing and acceptability of a fortified Cassava-based Product (gari) with Soybean. Nutrition and Food Science. 33(6): 278-283.

RICHARD J. L. 2007. Some major mycotoxins and their mycotoxicosis, an Overview. International Journal of Food Microbiology. 119: 3-10. https://doi.org/10.1016/j.ijfoodmicro.2007.07.019

RIZZO G. \& BARONI L. 2018. Soy, soy foods and their role in vegetarian diets. https://www.ncbi.nlm.nih.gov/pmc/articles/PMC5793271/

SHOTWELL O. L., HESSELTINE C. W., BURMEISTER H. R., KWOLEK W. F., GAIL M. SHANNON \& HALL H. H. 1969. Survey of cereal grains and soybeans for the presence of aflatoxin. II. Corn and soybeans. Cereal Chemistry. 46(5): 454-463.

SHURTLEFF W. \& AOYAGI A. 2007. History of Soy in Africa. Vol. 6, No. 14. Soyinfo Center, Lafayette.

SMITH J. E., SOLOMONS G., LEWIS C. \& ANDERSON J. G. 1995. Role of mycotoxins in human and animal nutrition and health. Natural Toxins. 3: 187-192. https://doi.org/10.1002/nt.2620030404

USDA National Nutrient Database. 2004. http://www.Nal.Usda.Gov/ fnic/foodcomp/data/sr17/sr17.Html

WILLIAMS J. H., PHILLIPS T. D., JOLLY P. E., STILES J. K., JOLLY C. M. \& AGGARWAL D. 2004. Human aflatoxicosis in developing countries: a review of toxicology, exposure, potential health consequences, and interventions. American Journal of Clinical Nutrition. 80(5): 1106-1122.

\section{How to cite this article:}

NNAMANI G. C., GANA A. S., SHAAHU A., MSAAKPA T. S., LEMIBE P. C., NNAMANI M. A. \& NWANYANWU E. O. 2021. Effects of aflatoxin on soybean. J. Plant Develop. 28: 161-168. https://doi.org/10.47743/jpd.2021.28.1.855 